\title{
The Impact of Online Learning on the Learning Motivation of Junior High School Students
}

\author{
Zaitun $^{1}$, M Sofian Hadi ${ }^{2}$, Pinkan Harjudanti ${ }^{3^{*}}$ \\ ${ }^{123}$ Universitas Muhammadiyah Jakarta \\ *Corresponding author, e-mail: pinkanharjdnt@gmail.com
}

Received May 30, 2021; Revised May 31, 2021;

Accepted June 02, 2021; Published Online 2021-06-03

\section{Conflict of Interest Disclosures:}

The authors declare that they have no significant competing financial, professional or personal interests that might have influenced the performance or presentation of the work described in this manuscript.

\begin{abstract}
Online learning is a basic need of education in the 21st century. The benefits of online learning are felt in the continuity of education during the Covid-19 pandemic. This study aims to examine the impact of online learning on the learning motivation of Junior High School students. The results of the research discussion indicate that online learning has advantages, namely 1) as a medium to encourage independent learning; 2) as an effort to modernize the concept of education in the 21 st century; 3 ) increasing the intensity of the interaction between teachers and students; 3 ) allows for an interaction that is not limited to space and time, and 4) meaningful learning. The impact of online learning on student learning motivation tends to be negative due to the unpreparedness of various parties, including teachers, parents, students, and schools. Early adolescents who need direct guidance, direction, and motivation must lose control due to reduced direct interaction with the teacher. The monotonous implementation of online learning, lack of direction and supervision, pressure for students to study from home, and low teacher innovation are the main causes of decreased learning motivation due to online learning.
\end{abstract}

Keywords: Education, Online Learning, Learning Motivation

\section{Introduction}

Education is an effort that is held to empower individuals to become whole human beings so that they can more actualize, understand, and support themselves (Nurrohim, 2020). Providing quality education is an effort to fulfill national ideals in terms of educating the nation's life. Therefore, education is the spearhead of efforts to advance the quality of the nation. The more qualified human resources that are owned, the more recognized the quality of the country in the eyes of the world. The realization of quality education will not be obtained if the educational process is not supported by students, educators, and learning supporting infrastructure. Educational subjects that are currently shifting to students demand a major overhaul of the learning system and patterns in the classroom. 
The challenges of 21st-century education also require educators to integrate technology in every lesson. Changes in the paradigm of habits of society that are increasingly dependent on technological advances require students to also be ready to accept these changes. Therefore, teachers are expected to have better skills to motivate students in learning through the use of technology. The demands for technology use are increasing along with the covid-19 pandemic. The disease outbreak also changed the paradigm of the educational process which became increasingly difficult. The world of education which always emphasizes direct or face-to-face interaction is constrained in its implementation. Face-to-face learning is prohibited from being held for a while until conditions stabilize. Concern over the new cluster of the spread of the Covid-19 virus in the school environment became the main consideration of the government which was later alternated through various educational program schemes.

The Covid-19 pandemic hinders the face-to-face learning process, but on the other hand, the learning process cannot be stopped so that the government seeks to have online or online learning. According to Sadikin \& Hamidah (2020), online learning is learning that is organized through indirect interaction with support for accessibility, connectivity, flexibility from the internet network. The advantage of online learning is that the learning process can foster self-regulated learning. However, the situation in the field shows different things, some research results state that online learning causes various problems. Setyorini's research (2020) states that the implementation of online learning during the pandemic adds to social problems considering that mastery of technology by human resources is immature, access to online learning requires quite expensive quotas, less than optimal parental assistance, decreased quantity and quality of interactions in learning, and educators' working hours are becoming increasingly unlimited because they rely on online media to communicate with students.

The transformation from face-to-face learning to online learning that has occurred suddenly since the beginning of 2020 has caused the unpreparedness of various parties, both educators and students. Therefore, online learning which should bring benefits in providing virtual classrooms confuses those involved in learning. Reducing the intensity of the interaction between educators and students can encourage the emergence of learning loss (loss of interest in learning). Therefore, online learning mediation cannot be maintained for long. Online learning was originally a necessity for students to be more independent as learning subjects, but in the current situation, it encourages a decrease in interest and motivation to learn. Thus it is clear that the implementation of online learning must still be combined with face-to-face learning so that learning loss does not occur.

The problem of using technology is the main thing that must be controlled in the effort to implement online learning. The limited mastery of advanced technology such as smartphones in learning can be one of the main causes of the ineffectiveness of online learning (Hafida et al, 2020). The decreasing level of learning effectiveness, the more it causes a decrease in the motivation and activeness of students in learning. Motivation to learn is an effort that is exerted so that individuals are encouraged to take certain actions related to learning efforts to achieve the expected results. Therefore, a decrease in learning motivation during online learning can reduce the quality of student learning outcomes. This condition can occur at various levels of education. However, the most severe impact will be felt on children who are in the middle level who are out of control of their parents and on online learning that is also out of control from the teacher. Students at the Junior High School (SMP) level are included in the early adolescence stage with an age range of 12-15 years who need support and attention in achieving their developmental tasks (Sari et al, 2018). Therefore, junior high school-age students need more support in online learning to obtain maximum learning outcomes.

Motivation to learn at junior high school age will not be formed without attention from the learning environment, namely parents and teachers. According to Maulida (2009), education in adolescence in social and psychological aspects is very concerning because there are many problems including laziness in learning, irregular learning, not doing assignments, skipping lessons, and cheating on exams. Learning transformation with an online learning approach makes students lazier. This is coupled with the monotonous quality of learning because teachers do not innovate so that learning motivation is not well-formed. Discussions through virtual classrooms are less effective because students who hold their smartphones without parental supervision and teachers tend to prefer playing social media and online games. Therefore, online learning can only be used as a supportive approach in learning and cannot entirely replace the quality of face-to-face learning.

The implementation of online learning in the long term will make students more saturated with the learning process. In fact, the learning process during online learning only contains assignments given by 
educators, so that without supervision it makes students even more reluctant to learn. According to Robandi \& Mudjiran (2020) online learning only confuses students and information and material are delivered directly so that it piles up. This situation tends to make students leave school for various reasons such as not having smartphone support, economic difficulties in completing school administration, and difficulty buying quotas. Therefore, the decrease in motivation to learn makes some children finally decide to leave school and work at a very early age. If the online learning scheme is further extended, not only will a decrease in learning motivation and learning loss occur, but also an increase in the dropout rate due to the pandemic situation pressing the community's economy.

Based on the background of the problems described above, it can be concluded that online learning is a way for efforts to maintain learning continuity during the pandemic, but the learning scheme cannot be held for a long time because it can reduce learning motivation which in turn causes learning loss. The purpose of writing this article is to examine the impact of online learning on student motivation in junior high schools. The results of the discussion are expected to be able to provide an overview and reference for actions to restore student interest and motivation to learn, especially for children who are in the early adolescent phase.

\section{Method}

This research uses the library research method, where the collection of information and data uses materials and materials in the library, namely, journals, news, and scientific articles related to the implementation of online learning during the Covid-19 pandemic. The scientific articles in question are articles obtained from National journals. The data and information that has been obtained are then collected, analyzed, and concluded so that they can be understood by the reader.

\section{Results and Discussion}

\section{Online Learning during the Covid-19 Pandemic}

Education is an ongoing process and cannot be separated from the impact of the surrounding environment. Online learning is a necessity within the framework of modern education. If education is far behind the times, especially in scientific and technological developments, it can be ascertained that the education held can no longer bring relevant benefits to students. Online learning is also an alternative for providing education during the Covid-19 pandemic. Online learning is the last option in learning patterns. According to Ibrahim \& Suadirman (2014), there are three learning patterns, namely 1) conventional patterns that only place the teacher as the main subject in learning; 2) the pattern of teachers and media that combines the role of the teacher as the central subject of learning with the support of instructional media; and 3) independent patterns that encourage students to interact directly with learning media. Thus, online learning during the Covid-19 pandemic is an implementation of independent learning patterns that encourage students to connect directly with learning media.

Online learning during a pandemic is a form of distance learning that fulfills the concept of physical distancing or social distancing recommended by the government. Students are not allowed to study directly at school because it is feared that it will cause crowds, while direct interactions that occur in learning at school are also feared to open up opportunities for the spread of the Covid-19 virus in schools (Latip, 2020). Online learning can only be implemented if there is support from the availability of e-learning or electronic learning tools. According to Nurfitriana \& Zulfah (2020) e-learning is a concept of using technology that transmits a series of solutions or information in terms of teaching. Thus, online learning is a learning effort that is intermediated by e-learning, which in this case can only be realized if there is internet network support.

The use of electronic media in the online learning process can be said to be an effort to involve students in the learning process who play an active role as learning subjects. The initial goal of online learning is to provide more positive motivation to learn so that it is motivated to be active in learning. The government's decision not to need to meet learning outcomes also provides more leeway for students to be more relaxed in learning. Online learning also provides flexibility for students to be able to study anywhere and anytime (Komarudin \& Prabowo, 2020). However, this concept has been misinterpreted by several parties, including students and parents, who think the school has been closed for a long period of time. This disagreement tends 
to cause conflict that ends in students out of control from two sides, both from school and parental supervision.

The constraints in implementing online learning also stem from the geographical conditions in Indonesia. The results of the 2020 Indonesian Digital Report survey show that internet users in Indonesia have reached $64 \%$ of the total population. This means that there are still $36 \%$ who have not been able to access the internet. This has resulted in gaps in learning which have an impact on decreasing the quality of education. Limited facilities make students lazy in learning. Monotonous innovation from teachers in organizing online learning is also one of the factors inhibiting the success of learning during the pandemic. Online learning, which is an extension of the distance learning concept, has been agreed to be held without having to meet the achievement indicators of the educational curriculum. Teachers are still obliged to deliver learning material even though interactions are physically limited during a pandemic. The teacher is also obliged to ensure positive feedback on the learning carried out. This is also the background for the home visits conducted by several teachers during the pandemic to ensure the situation of students. Therefore, it can be concluded that the responsibility of teachers during the pandemic is increasing even though the concept of student independence in learning is highly emphasized.

\section{Impact of Online Learning on Education}

The implementation of online learning has occurred for more than one year. Evaluation of the implementation of these activities must be carried out so that education in Indonesia does not lose the meaning of its basic goal, namely to educate the nation's generation. There are three main components in education that must be considered in implementing online learning in the form of students, educators, and the technology used. When referring to the learning theory with a cognitive learning approach, the learning process takes precedence over learning outcomes. This is following the concept of online learning which does not require specific learning outcomes, but only emphasizes the independence of students in learning independently. Online learning brings positive and negative impacts simultaneously. The following is the impact of online learning for learning in junior high schools based on a review of previous studies.

a. Online learning as a medium to encourage independent learning

Junior high school students are part of their early adolescence that require maturation from a social, mental, and psychological perspective. Learning independently requires habituation so that a pandemic situation can also be used as an exercise to better recognize self-potential. The learning flow that was initially obtained centrally from teacher to student, is now being changed from student to student. This means that students are expected to be able to find and solve learning by themselves and the teacher only acts as a facilitator. This concept is also in line with the 2013 curriculum which encourages student activity in learning. Students are expected to be active actors in learning so that they can internalize educational values (Komarudin \& Prabowo, 2020). Meanwhile, according to Handrini \& Wulandari (2020) students determine their criteria for the completeness of understanding the material in learning. Therefore, student knowledge is determined by students independently. As for the long term, independent learning also makes a significant difference in learning outcomes.

\section{b. Online learning is an effort to modernize the concept of 21 st-century education}

Online learning, online learning, or "online" learning means connecting students and teachers online through fun learning not only relying on books, but also using a smartphone, laptop, or computer (Robandi $\&$ Mudjiran, 2020). The existence of online learning answers the challenges of competition in the era of globalization. The introduction of technological sophistication for learning should be used from an early age, considering that students at junior high school generally tend to only know online games. Competency demands on junior high school students are increasing because this phase is the middle phase that will determine the success of the next level. Junior high school graduates who continue to high school and collegelevel still have the opportunity to learn soft skills and technology for a long time, but for those who wish to continue to the SMK level and work, the term "technological literacy" is necessary.

c. Increase the intensity of the interaction between teachers and students

Social restrictions to learning from home policies have hindered the implementation of face-to-face learning. The use of e-learning in the context of implementing online learning can maintain the continuity of the learning process while adhering to health protocols, to protect students from the spread of the covid- 
19 virus. The use of e-learning can save time in learning, save on transportation costs, save on education and infrastructure costs, simplify school equipment and books, and be able to reach students who are in a wider geographical range (Nurfitriana \& Zulfah). This also fulfills the development needs of the early adolescent phase who tend to try to build good relationships so that they are accepted by their environment (Sari et al, 2018). The need for affiliation during the pandemic was hampered by the banning of crowds. Therefore, the intermediation of relationships through e-learning can maintain the intensity of the relationships that are fostered both with teachers and with classmates through online class discussion groups.

d. Allows interaction that is not limited to space and time

Online learning is held by involving students without having to be in a unity of space and time. Students can access the material without a certain time limit. This means that as long as students have access to the internet, it can be ascertained that they can access the material provided by the teacher. Junior high school students who generally don't have their smartphones can wait for their parents to come home from work so they can access the material provided. This also facilitates parental supervision of the quality of student learning independently, considering junior high school students are individuals who still really need the support of teachers and parents. Meanwhile, during the pandemic, the full role of the teacher is also the role of parents. Therefore, to ensure the success of a learning scheme that is not bound by time and space formally requires collaboration between teachers and parents. The nature of adolescents who want to be accepted by their environment must be controlled so that the freedom obtained as a result of the impact of the pandemic can be accounted for wisely.

\section{e. Learning meaning}

Meaningful learning is the goal of the 2013 curriculum concept which encourages students to be more active in learning. Direct interaction drives the existence of meaningful interactions between teachers and students so that it can generate learning desire or motivation (Robandi \& Mudjiran, 2020). Meaningful learning is expected to be able to make students have a complete package of knowledge, skills, and superior character. Meanwhile, meaningful learning can only be realized if the teacher can build a pleasant learning atmosphere according to the student's personality. Therefore, teacher innovation in online learning is the main point of successful learning. Especially for junior high school students who have not been able to adapt to environmental changes.

The positive side of online learning is also followed by negative impacts that affect the quality of education as a whole. The transition from senior status in elementary school to junior high school becomes a stressor for early adolescents who have low adjustment abilities (Poerwanto \& Prihastiwi, 2017). This is what causes dissatisfaction and a lack of student responsibility in participating in learning. Laziness is the main impact caused by this transitional phase. As for the implementation of online learning, efforts are made to maintain business continuity but have not been maximized due to gaps in learning facilities. The higher the gap in the facilities for supporting online learning activities can encourage a high gap in learning outcomes.

Difficulty in prolonged online learning can eliminate student motivation. The direct interaction between teachers and students that has begun to decrease due to the pandemic reduces motivation and eliminates the motivation or desire to learn from within students (Nurfitriana \& Zulfah, 2020). Teacher control in online learning is limited by space because the learning system is carried out remotely, but the time required for online learning is increasing. This can be seen from the completion of tasks that tend to exceed the deadline so that the teacher must make continuous corrections. Early adolescence tends to have an interest in new things so that the freedom to use a smartphone is misused for purposes other than learning. The survey shows that as many as $16.68 \%$ of the population in Indonesia are adolescents aged 13 to 18 who use the internet (Kompas, 2018). Poerwanto \& Prihastiwi's research (2017) shows that junior high school students tend to be addicted to gadgets, especially to access online games that do not support learning.

\section{The Impact of Online Learning on Junior High School Student Learning Motivation}

According to Ibrahim \& Suardiman (2014) learning motivation can be measured from several aspects, namely curiosity, efficacy, attitude, need, competence, and external motivators. The concept of online learning is good enough to meet the needs of the 21 st century as well as handling and prevention during a pandemic, however, almost more than one year of online learning has not fully increased the activeness of students in learning. The implementation of education according to the 2013 curriculum must meet the basic 
principles of student-centered learning, this is directly fulfilled by online learning which associates understanding knowledge with the principle of independence. The 2013 curriculum also emphasizes the development of student creativity, while online learning also fulfills this concept because the achievement of curriculum indicators is not generalized as before. The 2013 curriculum also expects the creation of pleasant classroom conditions to provide a diverse learning experience, as for this aspect, online learning is sufficiently fulfilled because teachers are given the freedom to use any media that can be used to communicate with students. However, the communication built-in online learning is often one way, so that students' learning motivation does not increase.

Haryadi \& Rosiana's (2020) research results show that online learning harms student learning motivation. This shows that the longer the application of online learning, the lower the student's motivation to learn. The motivation to learn can only grow if the laziness in oneself is eliminated. Factors that influence laziness in learning can be intrinsic or extrinsic factors. Laziness can be caused by a decrease in motivation to learn if the individual does not know the benefits of learning. The cause of laziness also comes from psychological and physical conditions. Online learning, which seems simple, actually takes up a lot of time. Conditions in the field indicate that almost every teacher assigns assignments every day. This can make students feel bored and tired so they are lazy to take part in further learning. The affordability of access to learning from home also makes students divide their time with homework so that they can only do assignments at certain times.

Robandi \& Mudjiran's (2020) research results show that the average learning motivation of junior high school students tends to be low. Online learning is only carried out monotonously over a long distance so that it affects student learning motivation. Students of junior high school age require the realization of peerto-peer affiliation. Social restrictions that are applied eliminate the opportunity for children to gather with classmates. Students are required to understand the material independently, while the teacher does not provide direct assistance. The decrease in the quality of this interaction triggers rebellion in the child so that he chooses not to be active in learning, does not collect assignments, and also does not answer when the teacher contacts personally. The distance created through online learning also eliminates the opportunity for teachers to provide response-punishment or simply provide motivation. Therefore, the decline in education is very pronounced not only in the cognitive and skill aspects but also in the quality of the character of the nation's children.

According to Setyorini (2020) online learning causes problems related to students, teachers, and parents because mastery of technology is still low, additional tasks for parents in accompanying learning, additional education costs for quotas, low communication intensity between teachers and students, teacher working hours become irregular, coordination between teachers and parents is also hampered. These problems further make students' enthusiasm for learning decrease. Junior high school-age adolescents need support, motivation, stimulus, and direction from the immediate environment in learning. Therefore, the implementation of online learning alone is not able to frame students' learning needs. Extension of online learning in the long term can cause learning loss or the phenomenon of students losing opportunities to learn and increase knowledge. The essence of learning has a broad meaning because it is not only academic ability, but also emotional development, social interaction, and personality formation (Maulida, 2009). If junior high school children are allowed to learn independently and graduate easily, there is a risk of causing loss generation. The character of students as junior high school children does not change due to learning loss, meaning that continuation of levels in education which is only done online learning cannot shape the knowledge and personality of students. The long-term situation can lead to a decline in the quality of the nation's generation and children who continue their education to the next level still have the same thoughts. High school students in the future will still have thoughts, personalities, and knowledge like junior high school students, and so on.

The combination of face-to-face (offline) learning and online learning (online) is necessary so that the impact of learning loss can be mitigated. Bronfenbrenner's theory proposes that the microsystem proposes factors that directly influence such as parents, teachers, friends, and school so that these factors must be able to fully understand, supervise and motivate adolescents (Maulida, 2009). Online classroom management should appeal to teenagers. Therefore, the teacher plays an important role in presenting the learning process with a social and emotional approach that is easily accepted by adolescents. The efforts made by teachers and parents are expected to be able to build the core of learning motivation, namely encouragement and mental strength that is oriented towards meeting educational goals (Ibrahim \& Suardiman, 2014). Quality learning outcomes are also determined by the effectiveness of learning time, which aspect is a big challenge 
in the implementation of online learning. Students tend to have difficulty determining effective study time at home because the family environment does not support students' focus on learning. Therefore, this requires close coordination between teachers and parents to further condition a good learning climate. The better the coordination carried out, the more comfortable the students are so that it is also able to prevent an increase in the dropout rate.

\section{Conclusion}

The dynamics of education in Indonesia are quite affected by the impact of the Covid-19 pandemic. The integration of online learning (online learning) into the education curriculum is fully implemented during the pandemic. The main objective of implementing online learning is to maintain the continuity of learning in a period of social restriction. The biggest challenge during the implementation of online learning in general concerns knowledge, skills, academic culture, values, attitudes, and the readiness of supporting infrastructure for online learning. The concept of online learning is quite capable of implementing the 2013 curriculum, which is student-centered learning with an emphasis on independent learning while preventing the spread of the Covid-19 virus.

Analysis of several previous studies shows that almost more than one year of online learning has not fully increased the activeness of students in learning. Laziness and boredom are the main characteristics of adolescents at the age of junior high school children because support and attention are still the main focus for them. The flexibility obtained from online learning is misused and not on target so that communication that occurs in learning tends to go in one direction. Early adolescent developmental age also requires meeting the needs of affiliation and being recognized by the environment. The social restrictions due to the pandemic have alienated these children from their peers, thus decreasing student motivation in learning. The presentation of accumulated material and the confusion of the rapidly changing online system are also some of the causes of low student motivation.

The skills of teachers in presenting material with monotonous methods and media and students who only access material from home are the main causes of decreased student motivation. If student motivation is allowed to decline during online learning, it can cause learning loss. The consequence of this is that knowledge and personality are not fully formed so that the character of junior high school students is stagnant even though they have continued their education to the next level.

\section{References}

Fatimah. 2018. Berapa Jumlah Pengguna Internet Indonesia?. Retrieved from https://tekno.kompas.com/read/2018/02/22/16453177/berapa-jumlah-pengguna-internetindonesia

Handarini, O.I., \& Wuandari, S.S. 2020. Pembelajaran Daring Sebagai Upaya Study From Home (SFH) Selama Pandemi Covid 19. Jurnal Pendidikan Administrasi Perkantoran (JPAP), 8 (3), 496-503.

Haryadi, R., \& Rosiana, I. 2020. Pengaruh Sistem Pembelajaran Daring Terhadap Motivasi dan Kualitas Belajar Siswa. Jurnal Jurusan Bimbingan Konseling Undiksha, 11 (2), 136-141.

Ibrahim, D.S., \& Suardiman, S.P. 2014. Pengaruh Penggunaan E-Learning Terhadap Motivasi Dan Prestasi Belajar Matematika Siswa SD Negeri Tahunan Yogyakarta, Jurnal Prima Edukasia, 2 (1), 66-79.

Komarudin \& Prabowo, M. 2020. Persepsi Siswa Terhadap Pembelajaran Daring Mata Pelajaran Pendidikan Jasmani Olahraga Dan Kesehatan Pada Masa Pandemi Covid-19. Majalah Ilmiah Olahraga (MAJORA), 26 (2), 56-66.

Latip.A. 2020. Peran Literasi Teknologi Informasi Dan Komunikasi Pada Pembelajaran Jarak Jauh Di Masa Pandemi Covid-19. EduTeach : Jurnal Edukasi dan Teknologi Pembelajaran, 1 (2), 107-115.

Maulida, R. 2009. Problem Malas Belajar Pada Remaja (sebuah Analisis Psikologis). Jurnal Tsaqafah, 3 (2), $129-144$.

Nurfitriana \& Zulfah. 2020. Penerapan E-Learning dengan Aplikasi Zenius untuk Meningkatkan Motivasi Belajar Siswa SMP Negeri 2 Kampar Utara. Journal on Education, 3 (1), 62-75. 
Nurrohim, N. 2020. Analisis Kepuasan Siswa Kelas IX Sekolah Menengah Pertama Terhadap Pembelajaran Daring Mata Pelajaran PJOK Pada Masa Pandemi Covid-19 Kecamatan Purwanegara 2020, Journal of Physical Activity and Sports, 1 (1), 133-146.

Poerwanto, A., \& Prihastiwi, W.J. 2017. Analisis Prediktor Resiliensi Akademik Siswa Sekolah Menengah Pertama di Kota Surabaya. PSIKOSAINS, 12 (1), 45 - 57.

Robandi, D. \& Mudjiran. 2020. Dampak Pembelajaran Dari Masa Pandemi Covid-19 terhadap Motivasi Belajar Siswa SMP di Kota Bukittinggi. Jurnal Pendidikan Tambusai, 4 (3), 3498-3502.

Sadikin, A. \& Hamidah, A. 2020. Pembelajaran Daring di Tengah Wabah Covid-19. BIODIK: Jurnal Ilmiah Pendidikan Biologi, 6 (2), 214-224.

Sari, A.P., Neviyarni, \& Ifdil. 2018. Kebutuhan Afiliasi Siswa. Jurnal Konseling dan Pendidikan, 6 (3), 191 197.

Setyorini, I. 2020. Pandemi Covid-19 dan Online Learning : Apakah Berpengaruh Terhadap Proses Pembelajaran Pada Kurukulum 13?. Journal of Industrial Engineering \& Management Research (JIEMAR), 1 (1), 95-102. DOI: https://doi.org/10.7777/jiemar.v1i1

Article Information (Supplementary)

Conflict of Interest Disclosures:

The authors declare that they have no significant competing financial, professional or personal interests that might have influenced the performance or presentation of the work described in this manuscript.

Copyrights Holder: <zaitun> <2021>

First Publication Right: BISMA The Journal of Counseling

https://doi.org/10.xxxx/xxxxx

Open Access Article | CC-BY Creative Commons Attribution 4.0 International License.

@creative

Word Count: 